\title{
Redistribution with Sloth-Britain's problem?
}

\section{Richard Jolly}

Many if not most economic analyses of Britain's economic difficulties suggest that slow growth is at the heart of the problem-and an acceleration of growth the obvious cure. Past experience in Britain and in the Third World casts doubts on this. Except for the last three or four years, per capita growth rates in Britain since the war have been almost as fast or faster than at any time since the start of the industrial revolution. In terms of unemployment, income distribution and export-import balance Britain's post-war performance has also been better than for most of the last century.

Recent work on developing countries has shown that poverty, employment problems, inequality, foreign exchange difficulties and heavy international 'dependence' arise as much from the structure and pattern of a country's development as from its growth rate. Similarly, the eradiction of these problems depends as much on structural change as on growth. If this is true for poor countries why not also for a country like Britain, very much richer and much more industrialised? Instead of our somewhat naive faith in growth and our short run monetarist or neo-Keynesian preoccupations-should we not direct economic policy much more explicity towards what is needed to restructure the British economy in the short and over the longer run? Such restructuring would need to focus on a number of issues, but the concepts of basic needs and national selfreliance, approaches and priorities suggested in analyses of Third World problems, interpreted within the context of a still relatively rich, industrialised country, might provide helpful guidelines. It is not even clear that aggregate growth has more than a minor part to play in the process.

\section{Britain's past economic performance}

Since the industrial revolution began about two centuries ago, the long-run pattern of British economic development has been of very slow but relatively steady growth. There was little or no redistribution, except for the major and very important reduction in inequality between the slump of the 1930s and the establishment of the welfare state by the mid 1950s.1 The distinctive long run characteristic of the British pattern has been creeping growth rather than creeping socialism.

The long-run trends in British growth can be judged by the rates of increase of real GNP over the 30 years periods, shown in Table 1 . The trend growth rate was just under 3 per cent per annum over the first part of the 19th century, dipped to just under $2 \frac{1}{2}$ per cent per annum in the middle and ended at just over 3 per cent. The average growth rate over the whole century was virtually identical to the 2.7 per cent per annum achieved over the period of nearly three decades following the second world war (1946-73). (Taking account of the last three or four years stagnation, the 1946-76 rate would be somewhat lower, probably 2.3 per cent per anum).

Table 1

British Economic Growth-long term growth rates (average annual percentage increase)

$\begin{array}{lcc}\text { Year } & \text { Real GNP } & \begin{array}{c}\text { Real GNP } \\ \text { per capita }\end{array} \\ 1700-1745 & 0.3 & 0.3 \\ 1745-1785 & 0.9 & 0.3 \\ 1780-1800 & 1.8 & 0.3 \\ 1801 / 11-1831 / 4 \mathrm{~J} & 2.9 & 1.5 \\ 1811 / 2 \mathrm{~J}-1841 / 51 & 2.9 & 1.4 \\ 1821 / 31-1851 / 61 & 2.3 & 0.4 \\ 1831 / 41-1861 / 7 \mathrm{~J} & 2.2 & 0.4 \\ 1841 / 51-1871 / 71 & 2.5 & 1.4 \\ 1851 / 61-1881 / 91 & 3.2 & 2.0 \\ 1861 / 71-1891 / 1901 & 3.3 & 2.2 \\ 1901-1913 & 0.9 & 0 . J \\ 1921-1937 & 2.1 & 1.7 \\ 1938-1946 & 1.5 & 1.7 \\ 1946-1956 & 2.4 & 1.5 \\ 1956-1966 & 2.8 & 2.1 \\ 1966-1973 & 2.8 & 2.4 \\ 19 \text { th century average } & 2.7 & 1.4 \\ 1946-1973 & 2.7 & 2.0\end{array}$

Source:

until 1901-Phyllis Deane and W. A. Cole, British Economic Growth

20th century--calculated from British Economy-Key Statistics 1900-1966 and recent N1ESR reports.

In contrast with this slow, long haul of growth, redistribution of personal incomes has been quantitatively signficant only in this century. Although there appear to have been minor improvements in the distribution of income in the quarter-century or so before 1914 , when the basis

1 Over the last few years, rapid inflation and various controls in incomes and profits appear to have brought other changes in distribution-though it is too early to assess reliably the extent of these or how permanent they will be. 
for further changes was laid, the one major improvement in the last two centuries occurred in the two decades between the mid-1930s and the early 1950s. Over this period both pre-tax and posttax income distribution improved substantiallythe result of a marked reduction in unemployment and the introduction of a range of welfare state measures following the Second World War. ${ }^{2}$

Britain's comparative standing with other developed countries in respect to post war income distribution can be judged from Table 2 . national income in 1801 but had fallen to 4 per cent by $1948 / 57$. Moreover, the share of profits, interest and mixed incomes halved from about 40 per cent to about 24 per cent over the same period ( 21 per cent by 1966 , even lower in the last few years), though all of the latter decline took place during this century. In contrast employment incomes have increased-from some 44 per cent of national income in 1801 to some 73 per cent in 1966.

In terms of the living standards and styles of

Distribution of Post-Tax Income in OECD Countries

Table 2

(percentage share of personal incomes by quintile groups)

\begin{tabular}{|c|c|c|c|c|c|c|}
\hline & Year & $\begin{array}{c}\text { Bottom } \\
20 \%\end{array}$ & $\begin{array}{c}\text { Middle } \\
60 \%\end{array}$ & $\begin{array}{l}\text { Top } \\
20 \%\end{array}$ & Total & $\begin{array}{l}\text { Ratio top to } \\
\text { bottom } 20 \%\end{array}$ \\
\hline Australia & $66 / 7$ & 6.6 & 54.6 & 38.8 & 100.0 & 5.9 \\
\hline Canada & 69 & 5.0 & 54.0 & 41.0 & 100.0 & 8.2 \\
\hline France & 70 & 4.3 & 48.8 & 46.9 & 100.0 & 10.9 \\
\hline Germany & 73 & 6.5 & 47.4 & 46.1 & 100.0 & 7.1 \\
\hline Italy & 69 & 5.1 & 48.4 & 46.5 & 100.0 & 9.1 \\
\hline Japan & 69 & 7.9 & 51.1 & 41.0 & 100.0 & 5.2 \\
\hline Netherlands & 67 & 6.5 & 50.6 & 42.9 & 100.0 & 6.6 \\
\hline Norway & 70 & 6.3 & 56.4 & 37.3 & 100.0 & 5.9 \\
\hline Spain & $73 / 4$ & 6.0 & 51.7 & 42.3 & 100.0 & 7.1 \\
\hline Sweden & 72 & 6.6 & 56.4 & 37.0 & 100.0 & 5.6 \\
\hline United Kingdom & 73 & 6.3 & 55.0 & 38.7 & 100.0 & 6.1 \\
\hline United States & 72 & 4.5 & 52.6 & 42.9 & 100.0 & 9.5 \\
\hline Average & & 5.9 & 52.3 & 41.8 & 100.0 & 7.1 \\
\hline
\end{tabular}

Source: OECD. Public Expenditure on Income Maintenance Programmes, OECD, Paris, July, 1976, p.109

Because only limited changes in the distribution of personal incomes occurred before the second world war, one must not assume that distribution in other respects has not changed. Income by factor shares has shifted markedly over the last two centuries. From the beginning of the 19th century to post second world war, the share of national income from all forms of rent declined dramatically. Rents were some 20 per cent of

2 Soltow, (1968) summarises the statistical evidence on income inequality in Britain, inevitably based on partial and occasionally fairly reliable data. The estimates show that the Gini coefficient of income distribution remained between 0.56 and 0.50 for the two centuries up to 1913 compared with 0.34 in $1962 / 3$. Soltow's judgement on the changes between the periods for which date are available are as follows: $1688-1801 / 3$ no change in inequality.

$1801 / 3-1867 / 80$ probably no change, just possibly

certainly no increase, possibly 10

per cent reduction.

1911/13-1962/3 substantial decrease in inequality.

Besides these changes in overall inequality, upper tail income tax data show evidence of continuous decline in inequality between 1801, 1911/12 and 1962/3.

The more recent evidence is summarised in the report of the Royal Commission on the Distribution of Income and Wealth, in R. J. Nicholson (1967), and B. Abel-Smith, and Townsend, (1965). Note that within the limitaticns of the data, most analysts agree that poverty and inequality were both significantly reduced over the decade or two until the early 1950 s - but that it is much more doubtful whether the process has continued thereafter. both the rich and the really poor, these have meant significant changes. From the beginning of the 20th century, for example, the share of home-rents had fallen from about 9 per cent of national income to about 3 per cent, largely reflecting rent controls and subsidised council housing. The gradual build up of unemployment relief and state pensions beginning with the Liberal reforms of 1906-14 were tremendously significant. $^{3}$ On the other side, so to speak, domestic service which formed 5 to 6 per cent of recorded output at the end of the 19th century has virtually disappeared in recent years (though it has been partly replaced by household equipment and non-household services). There is certainly no cause for complacency in the present crisis, with the threats it holds for the social services and the capacity or willingness of government to restore high rates of employment and effective welfare state policies, the two pillars on which the positive post war gains in income distribution rested. Nevertheless, the dramatic improvements over the extremes of poverty and inequality in earlier times should be recognised.

3 A good summary is available in Hay, 1975. 


\section{International changes}

Internationally, too, the recorded changes in net inflows of income and outflows of investment represent a very considerable contrast with the earlier position. Net inflows of income from abroad rose from about 1 per cent of GNP in the early 19th century to 7 or 8 per cent at the end and during the decade or so before the first world war. Thereafter net inflows of income from abroad have declined-to about 6 per cent of GNP in the 1920s, 5 per cent in the 1930s, 3 per cent immediately after the second world war and just over 1 per cent in the last two decades. More or less in parallel with this rise and fall, (but with considerable fluctuations) net foreign investment rose from 3 per cent of GNP in 1861 to nearly 7 per cent in 1911 , thereafter declining sharply, at times to the extent of net dis-investment or net capital inflows into Britain in the 1930s and afterwards. ${ }^{4}$ Over the whole period, net outflows of foreign investment have always been somewhat lower than inflows of net income from abroad although in recent years Britain has begun to pay its own way to a degree not seen for 100 years, if then.

The real signficance of these changing international relationships is indicated, however, less by the statistical 'shift' in income or investment flows than by the broader changes of political and economic institutions and structures which have influenced the pattern and terms on which international trade and investment takes place. The existence of the Empire and colonies meant that an important part of British trade and commercial involvement abroad was built up in secure and protected markets-protected through language, contacts and political influence, as well as by direct imperial preferences. The end of this structure and the earlier loss of Britain's technological lead removed many, though by no means all, of these important advantages. Part of Britain's post war difficulties have been the result of a forced adjustment to an international context in which Britain has had to compete economically as never before.

\section{The future implications-for unemployment}

How important is it to change these patterns for the future? Or put another way, how important

\footnotetext{
4 One can never be entirely sure of the meaningfulness of long term changes in recorded foreign exchange flows, since the prices and components on which they depend reflect structures and institutions which themselves may be changing. Britain's position as both a base for and host to the operations of international firms is especially significant in the area of investment and income flows, some of which may be unrecorded.
}

are growth and redistribution for tackling Britain's current economic difficulties and achieving her long run objectives?

In order to keep the discussion to a reasonable length, I will consider the question in relation to unemployment, which, together with inflation, is the most critical problem of the British economy today.

In Britain, as in several OECD countries, the rate of unemployment in 1976 was almost double the average of $1962-73^{5}$ (Table 3).

Table 3-Unemployment ratesa in OECD countries

\begin{tabular}{lcccc} 
& $\begin{array}{c}\text { Average } \\
1962-73\end{array}$ & 1974 & 1975 & 1976 \\
\hline United States & 4.6 & 5.4 & 8.3 & 7.5 \\
Canada & 5.1 & 5.4 & 7.0 & 7.1 \\
Japan & 1.2 & 1.4 & 2.0 & 2.1 \\
France & 2.2 & 2.7 & 4.1 & 4.0 \\
West Germany & 0.6 & 1.5 & 3.6 & 4.0 \\
Italy & 3.5 & 3.1 & 3.6 & 3.9 \\
United Kingdom & 3.1 & 2.9 & 4.5 & 6.0 \\
Total b & $\overline{2.8}$ & $\overline{3.3}$ & $\overline{5.1}$ & $\overline{5.2}$
\end{tabular}

a Standardised to international definitions

b Representing about $90 \%$ of OECD, including Australia. Finland, Norway, Spain and Sweden as well as countries listed above.

Source: National Institute Economic Review, 80, May 1977, p.29

At first sight-and still conventionally accepted by most analyses in Britain today-growth is the critical ingredient for expanding employment. For example, the NIESR analysis published in February, 1977, estimated that to reduce unemployment from $1.4 \mathrm{mn}$. to a full employment level of about $0.5 \mathrm{mn}$. "would need an increase of some 9 per cent in GDP-this it must be stressed, in addition to the increase of approaching 3 per cent per annum (reflecting the growth of output per head, together with the rather rapid increase in the labour force expected over the next five years) required merely to halt the rise in unemployment. Thus to return to full employment in five years, for example, would require an annual growth rate over the period of nearly 5 per cent". (National Institute Economic Review, 1977: 51).

The fact that even 5 per cent might be very difficult to attain-it is nearly double the rate of growth achieved over any significant period in Britain over the last two centuries-should itself be sufficient to suggest that to rely primarily

\footnotetext{
5 Appalling as the current level of unemployment in Britain may be, it is worth noting that in no less than 25 years of the present century, the rate of unemployment has been higher than the current rate, and in two-thirds of them, double the 1976 rate.
} 
upon growth to solve the unemployment problem is, to say the least, unsatisfactory.

Yet the same conclusion can be read-and in fact has now become the 'conventional wisdom'from the experience of many developing countries, where even growth at rates of 5 or 6 per cent per annum has usually proved inadequate to ensure more than marginal increases in wage earning employment, let alone decreases in unemployment. ${ }^{6}$

If we applied to Britain the lesson of recent employment studies in the Third World, we would emphasise structural factors among the main causes of unemployment, and structural change rather than growth as the critical need. A structural approach in this context would need to cover two sets of issues-1. analysis of the underlying trends and problems of the economy, emphasing structural factors in the pattern and components of production, technological change, consumption, external linkages, etc, not simply relationships between the aggregates of total demand; investment, consumption, etc. and 2 . a disaggregated analysis of unemployment itself, emphasising the different factors bearing on the unemployment problems of youth, women, older persons, etc. Both elements have been recognised as essential for the effective understanding of employment problems in Third World countries and of policies to tackle them.

A structural approach to policy would take one into a wide range of issues, many absent from the mainstream debate on employment policy in Britain: the pattern of technological advance and the need for a major shift of policy towards the small producers; integrated local development schemes with more central support for local planning; a more selective approach to foreign investment; a radical change of policy towards informal sector services and methods of production; changes in education; incomes policy; a restructuring of government revenue and expenditure with employment objectives in mind. Each of these and some other areas of policy would, of course, need to be expanded and analysed at length as, for instance, was done in the ILO report on Increasing Productive Employment in Kenya (from the summary chapter of which the above headings were taken). One would also need to consider the influences on labour force

6 See, for example, the ILO employment missions to Colombia (1970) Sri Lanka (1971) and Kenya (1972), in which members of the IDS were heavily involved. Several years ago it was suggested that the ILO might send an employment mission to Britain. Unfortunately little official interest was shown in this interesting idea. supply: population growth, changing participation rates particularly of women (which have been rising), retirement policy and the whole set of factors determining the composition of the labour force.

The key point is that an employment policy built up from such a structural analysis would differ fundamentally from one emphasising GNP expansion. Growth would probably still be involved -but it would be growth implied by the specifics of strategy to reach and maintain full employment and meet other social and economic objectives, rather than an aggregate goal from which the resources required to meet other economic objectives might hopefully be financed. And the specifics of these other social and economic objectives and of how to attain them would need to be made a central part of the debate on economic and employment policy, not left peripheral to it.

\section{Siructural change and the problem of poverty}

Such an approach would raise immediately the problem of poverty, clearly related to the problem of unemployment but conceptually distinct. (Indeed Third World analyses have emphasised that the two problems ought generally to be considered together, both for analytical and policy making purposes.) Some 7 to 13 per cent of the British population are estimated to fall below 'the poverty line' (as variously defined), less than in several other OECD countries but still unreasonably high (Table 4). Yet the amount by which their incomes in total fall short of the poverty line is only small, barely 1 per cent of GNP. The same is true, according to recent OECD reports, for a number of OECD countries (OECD, 1976). Long run growth is hardly a necessary and certainly not a sufficient condition to fill a gap of this size.

More significant, it is not clear that growth alone will even assist with the matter. According to the OECD study, for instance, expenditure on income maintenance programmes over the decade until 1972 rose nearly three times as fast as per capita income in Britain, yet poverty remained. In large part, this was because of widespread 'leakages' which meant that most of the resources provided for income maintenance went to persons other than the poor or, if they did reach the poor, were offset by other reductions in their incomes. Some 8 per cent of GNP was spent on income maintenance but only a fraction helped the poor. Again, the eradication of poverty in Britain, as in most of the other industrialised countries, is a matter of structural changes which 
will deal with the causes of this poverty, not just more money: the issue is not really one of GNP.

Table 4--Percentages of population below 'poverty line' in various OECD countries and expenditure on income maintenance programmes, in early 1970s

$\begin{array}{lccc} & \begin{array}{c}\text { Per cent population } \\ \text { below poverty line }\end{array} & \begin{array}{c}\text { Per cent of national } \\ \text { product spent on } \\ \text { income maintenance } \\ \text { programmes }\end{array} \\ & \begin{array}{c}\text { Standardised } \\ \text { definitions }\end{array} & \begin{array}{c}\text { National } \\ \text { definitions }\end{array} \\ \text { Australia } & 8 & 8.2 & \\ \text { Belgium } & 11 & (14.4) & 14.1 \\ \text { Canada } & 11 & 15.1 & 7.3 \\ \text { France } & 16 & 15.20 & 12.4 \\ \text { Germany } & 3 & - & 12.4 \\ \text { Ireland } & -5 & 24.0 & 6.4 \\ \text { Norway } & 5 & - & 9.8 \\ \text { Sweden } & 3 \frac{1}{2} & - & 9.3 \\ \text { UK } & 73 & 13.2 & 7.7 \\ \text { USA } & 13 & 11.9 & 8.0\end{array}$

Source: OECD op. cit. Table 27 and 1.

\section{Employment patterns-the wider issues}

The increasing need in Britain, as in most of the richer OECD countries, is to provide an environment for a richer and fuller life for all groups and classes within the country, not just in material terms, but in respect of a range of activities, self fulfilment, family life and social interaction, of freedom of choice and active participation whether at work or in leisure.

Each of us probably has our own pet hobby horses in respect of the new elements we would like to see in this remodelled world. With regard to employment, mine include complete flexibility after the age of 15 with respect to education, work and retirement patterns, with the ability to shift periodically between all three (including in and out of temporary periods of 'retirement' for men and women over one's lifetime-and tapering rather than complete retirement for older persons); more flexible housing patterns freeing people to move and change jobs more easily; and a better balanced and more conscious integration of small scale and informal employment opportunities for providing everyday goods and services with large scale production and provision only where really essential.

This is not the place to expand further on these points, let alone to suggest that these ideas are the most important of the many that would need to be drawn upon and worked out politically, socially and economically into a new pattern of development. The critical point is simply that such changes, if set in motion, would put the emphasis on structural change, rather than growth. Growth, as conventionally measured, might or might not increase. This would almost be beside the point. The ability of people to choose, to participate, to lead fuller lives, to do more of the things which prove really satisfying would have increased. Against achievements of this sort, 5 per cent growth seems totally inadequate as a goal, and almost irrelevant as the means to achieve such change.

\section{References}

Hay, J. R., 1975, The Origins of the Liberal Welfare Reforms 1906-1914, Macmillan, London

ILO, 1970, Towards Full Employment. A Programme for Colombia

ILO, 1971, Matching Employment Opportunities with Expectations. A Programme of Action for Ceylon

ILO, 1972, Employment, Incomes and Equality. A Strategy for Increasing Productive Employment in Kenya

Nicholson, R. J., 1967, 'The Distribution of Personal Income' in Lloyds Bank Review

OECD, 1976, Public Expenditure on Income Maintenance Programmes, OECD, Paris, July

Abel-Smith, B. and P. Townsend, 1965, The Poor and the Poorest, Bell, London

Soltow, L., 1968, 'Long-run Changes in British Income Inequality', Economic History Review 